\title{
Revisiting the critiques of Ivan Illich's Deschooling Society
}

\author{
Jon Igelmo Zaldívar \\ Universidad Complutense de Madrid
}

\begin{abstract}
Late in 1970, Harper and Row Publishers Inc. started working on the first edition of Illich's Deschooling Society in New York. In the spring of 1971 the book reached the libraries all over the world. On this essay I attempt to tackle the most important biographical features of the author of this book. Thus, I go over articles, book reviews, books, and unpublished theses written by scholars from the United States, Germany, Canada, Australia, Great Britain, Russia, Argentina, and France, which offer various reactions to Deschooling Society. Most of the analysis and critiques made on Illich's book were written in the early 1970's. These publications were not related, strictly speaking, to scholarly research. In the last forty years there were only nine theses on Deschooling Society. Although there has been a renewed interest in Illich since the beginning of the twenty first century, there is little academic research opening new ways and articulating new interpretations. Further research on Illich's thought - not limited to Deschooling Society - would enrich current efforts to integrate Illich's ideas into innovative pedagogical proposals.
\end{abstract}

\section{Introduction}

The history of the twentieth century pedagogy is incomplete without mentioning Ivan Illich's Deschooling Society [1]. This book still inspires academic researchers who want to explore some of the most radical positions on education. It also counts as a reference for people who want to research on the alternatives in education beyond the official system. Although Illich did not write much about educational institutions - just 18 articles since 1968 until 1971-, all his writings are currently essential to understand one of the most visionary outlooks in the last fifty years in the history of education. Illich's book is still a reference point, in terms of what could have happened in the beginning of the twenty first century in the western world, or what kind of alternatives people could have articulated in order to take out education and learning from schools.

In the last decade, educators trying to develop new critical pedagogical approaches paid particular attention to Illich's Deschooling Society. However, this effort has not been accompanied by debates in major academic journals. Consequently, works published in the early 1970's in American and French journals, such as Saturday Review, Social Policy, Harvard Educational Review, The School Review, Esprit and Les Temps Modernes, still represent the most articulated critique of Illich studies. In the first articles it is possible to observe detractors and defenders of Deschooling Society analysing the critical methods for study educational institutions. These arguments are eventually divided between those against and in favour of the school system. That exactly happens with the first research and books published in the 1970's.

The controversy over Illich's book disappeared in the 1980's. At that time, international inquiry on critical pedagogy focused on other authors and new resources began to gain prominence amongst critical scholars in the meanwhile. In the late 1990's and the first decade of the twenty first century new critiques were done on Illich's works as a result. Nowadays, Illich's friends in Mexico propose to update his radical criticism against modern institutions within the new political, economical and cultural context. Many universities and research groups have started revisiting his ideas in the United States and Canada. It is important to mention that the first review dedicated exclusively to Illich's thought, The International Journal of Illich Studies [2], was published in 2009.

\section{Ivan Illich (1926-2002)}

Ivan Illich must be considered one of the most influential intellectuals on education of the twentieth century. He was born in Vienna in 1926. In the 1940's he studied at the Roman Gregorian University and he became a priest in 1951. Five years later he traveled to New York in order to keep developing his academic career at Fordham University with Jacques Maritain as his mentor [3]. In New York he got in touch with the Puerto Rican immigrant community settled in Manhattan. In 1956, with the support of Joseph Spellman, cardinal of New York, Illich started working as a vice-dean in the University of Puerto Rico [4]. At the age of 30 he was able to speak eight languages: Spanish, Portuguese, English, French, Latin, Italian, German and Croatian. 
In the beginning of the 1960s Illich set up two centers in Mexico and Brazil, where he organized seminaries for missioners taking part in John XXIII's campaign in an attempt to modernize the Latin American Church [5]. In 1963 Ivan Illich, together with Valentina Borremans, opened a new center in Cuernavaca, México, named Centro Intercultural de Documentación (CIDOC). In this center people of different nationalities organized many seminaries dealing with a variety of topics. Some of the most important intellectuals who spent time at the CIDOC and took part in its activities were: Erich Fromm, Paul Goodman, Peter Berger, John Holt, Paulo Freire, Augusto Salazar Bondy and Susan Sontang [6].

In the 1960's Illich also promoted one of the most transcendental events against Church authorities [7]. Since 1960 he published several articles criticizing the way in which the Catholic Church took part in the programs promoted by the United States for Latin America. He presented several texts against the decision made by the Vatican to support a model of progress and development without concerning the situation in Latin America and people's needs. Most of these articles were published in the book entitled The Church Change and Development (1970) [8]. As a result, in the summer of 1968 the Congregation for the Doctrine of the Faith requested Illich to close down the center in Cuernavaca and to finish his project in México. He rejected to follow the orders of Vatican authorities and decided to continue his work at the CIDOC. Thus, in 1969 the New York Times published all the documents concerning Illich's process against Vatican authorities. He finally decided to continue being part of the Catholic Church without getting involved in its issues [9].

Late in the 1960's Illich started publishing several texts in journals, magazines and newspapers all over the world. His aim was to criticize the main modern institutions expanding their power at that time. As a consequence, he soon became one of the most famous radical critics of modern institutions and an important reference for people thinking on new possibilities of changing the world. His books were a reference point that opened debates, discussing topics such as the critic of progress (Celebration of Awareness, 1970) [10], problems of modern transports (Energy and Equity, 1973) [11], and medicine (Medical Nemesis, 1975) [12]. However, Deschooling Society was probably the book that reached the most significant impact in the 1970s. On this essay Illich gathered seven texts in which he showed his own perspective concerning education in the second half of the twentieth century, analysing education in most of the countries of the world. He considered it was the right moment to study the tragic consequences of promoting the institutionalization of education. He claimed that it was not too late to think of new ways of organizing people's learning and build up their own educational institutions.

The first rough draft of Illich's Deschooling Society was edited in Mexico by the CIDOC. In September 1970 a volume titled The Dawn of Epimethean Man and Other Essays [13] appeared in the collection «CIDOC Cuadernos». It was in this collection where the first chapters of Deschooling Society were included. Most of these texts were written by Illich as a result of the works developed in the Alternatives in Education seminary organized in Cuernavaca by Everett Reimer since 1968. In the first edition of Deschooling Society he finally published several months after this first rough draft seven chapters: "Why we must Disestablish School"; "Phenomenology of School"; "Ritualization of the Progress”; "Institutional Spectrum”; “Irrational Consistencies"; "Learning Webs"; and "Rebirth of Epimethean Man”. All these chapters had appeared several months before in different journals, magazines and reviews.

The first chapter of Deschooling Society was published the $2^{\text {nd }}$ of July 1970, in the American review New York Review of Books; the title given to the first publication was "Why We Must Abolish Schooling” [14]. Additionally, Kenneth Parsley encouraged Illich to write an article in order to summarize the topics discussed by him at the CIDOC in May 1970. The idea was to show arguments against schools to the people of the United States; arguments he had been working on from his days in Cuernavaca. On the other hand, "Phenomenology of School" was the first essay presented by Illich on the $16^{\text {th }}$ of February 1970 at Yale University [15]. Illich recognized that this text was the result of conversations with Hann Steger, Fred Goodman, Paul Goodman and Peter Berger.

The third chapter of Deschooling Society entitled "Ritualization of the Progress" was introduced for the first time by Illich in the conference Technology: Social Goals and Cultural Options in Aspen, Colorado the $23^{\text {rd }}$ of August 1970 [16]. Its original title was "Schooling: the ritual of progress" and it was published in the journal New York Review of Books, the $3^{\text {rd }}$ of December 1970. The fourth text was "Institutional Spectrum" and it was the result of the discussion held by Illich with Valentina Borremans and José María Bulnes Aldunate in Cuernavaca [16]. In this chapter Illich presents a very interesting way to define the role played by different institutions in the modern world. From Illich's point of view, schools were the most malevolent institutions of modernity.

"Irrational Consistencies" was the fifth chapter of Deschooling Society and it was introduced at a conference carried out by the American Educational Research Association in New York the $6^{\text {th }}$ of February 1970. Moreover, the text "Learning 
Webs", inspired in the guidelines discussed in a seminar at the CIDOC [16], was also published in the New York Times Review of Books in July 1971. The last chapter of Deschooling Society was "Rebirth of Epimethean Man”, text which was originally presented at a conference at the CIDOC to celebrate Erich Fromm's birthday in 1970. The last work was an attempt to present the Epimetheus perspective of proportionality as an example to inspire a new world. Illich considered it the key chapter of the book [17].

Nevertheless, Illich did not pay too much attention to educational issues after the publication of Deschooling Society. He focused on other topics in his later works and came to considered he had made some mistakes in his book about education. Thus, in the 1980s and 1990s he published significant books about the history of the Western civilisation: Shadow Work (1980) [18], Gender (1983) [19], In the Mirror of the Past (1989) [20], and In the Vineyard of the Text (1993) [21]. At that time he was interested in conducting researches on the new cultural turning point of the Western world under the influence of new technologies, especially on the way in which Western thought has been changing under the influence of the screen as an axial metaphor.

Meanwhile, some scholars in the educational academic context started studying his theses on education as well as some grassroots movements tried to open new educational practices following the alternatives defended by Illich in Deschooling Society. In the beginning of the twenty first century new approaches about Illich's ideas on education arose in the context of pedagogy. After his death in 2002 it was possible to identify at least three new ways to articulate Illich's critical thought on educational institutions. First of all, some researches have analysed Deschooling Society trying to articulate a theory organizing a new learning perspective opened by the web 2.0 tools in the new context of social networking. On the other hand, within the homeschooling movement new radical perspectives have arisen: the unschooling, for instance, whereby defenders not only advocate for the structure of children's education outside schools but also decided not to follow the school rules when structuring children's education. To conclude, many groups and researchers are working on Ivan Illich's texts on education by putting them into practice within new grassroots movements, such as indigenous movements or degrowth anti-capitalism alternatives. It can be said that Illich is still a reference for all of them.

\section{Literature Review}

Most of the reactions caused by Deschooling Society emerged in the 1970's. Although a great number of authors found the book challenging for those who work in the educational system and recognized it as a commendable piece of work, other critics stated that the alternatives offered by Illich were utopian and had no practical direction or application. Consequently, there was a clear division in all these approaches to Illich's thought between those who were against schools and those who defended educational institutions.

John Ohlinger and Collen McCarthy [22] published the first work to engage with Illich's Deschooling Society. Its title was Lifelong Learning or Lifelong Schooling? A Tentative View of the Ideas of Ivan Illich with a Quotational Bibliography, published in July 1971, just a few months after Illich's text. On this research Ohlinger and McCarthy introduced Illich's thought and the relevant features of his critic analysis regarding educational institutions. They also described the resources used in great detail; which formed the core of the work prepared by Illich during a seminar held in the College of Education at Ohio State University a few months before, in the winter of 1971.

Despite this early work, critical attention on Deschooling Society did not flourish until late 1971, reaching its zenith in the mid-seventies. One of the earliest articles on Illich's thinking, “All Schooled Up”, was published by Colin Greer [23] in Saturday Review in October 1971. In this text Illich was pigeonholed as a utopian anarchist intellectual who wanted to break down the modern state. According to Greer the most important mistake in Deschooling Society was that the author endorsed deschooling the educational system without establishing a step by step guide for transforming one of the most important institutions in the world.

In 1972 the journal Social Policy published a sequence of articles with the aim of responding to the ideas stated by Illich. In the issue of January/February and March/April seven texts appeared in a section entitled "Illich, Pro and Con": "My Ivan Illich problem" by Neil Postman [24]; “After Deschooling, Free Learning” by Ronald Gross [25]; "Need For a Risk Quotient” by Roy Fairfiel [26]; "Taking Illich seriously” by M. Rosen Sumner [27]; “After Illich, What?” by Judson Jerome [28]; “And It Still Is News” by Maxine Green [29]; and "The Case for Schooling America” by Arthur Pearl [30].

These seven articles published in Social Policy are excellent samples of the spectre of sympathies and rejections towards Illich's ideas. A great number of authors found the book challenging, especially for those who work in the educational system. They had traditionally thought that they were part of the solution in this troubled world but not the core of the problem, as Illich stated. Nevertheless, even if considering Illich's critique creative, most of the authors took the opportunity to defend schools in their articles; in fact, the alternatives offered by Illich 
were often disqualified, seen as utopian and with no practical direction or application.

On the other hand, in the issue of February 1972 of the Harvard Educational Review appeared another article in response to Deschooling Society. The author was Harvard professor Herbert Gintis [31] and his essay was entitled "Toward a Political Economy of Education: A Radical Critique of Ivan Illich's Deschooling Society". Although written from the perspective of an economist, this work was without doubt one of the most significant critical texts against Illich's theses. In his article Gintis recognized the importance of Illich's book. He admitted that his hypothesis was suggestive because he had broken with the tendency of thinking developed after the Second World War. Illich did not believe that improving the institutional mechanisms of educational institutions would improve or resolve social, economic and cultural issues. That was actually a new point of view at the beginning of the 1970’s.

Despite Gintis's interest in Deschooling Society, he observed mistakes in Illich's methodological approach to educational institutions. From his Marxist perspective, Gintis criticized Illich's in his attempt of explaining the problems of industrial capitalism through an analysis of a part of the whole system. According to Gintis, issues like alienation in capitalist social and political structures could only be explained by studying the means of productions in the capitalist system, and not by analysing institutions used by capitalism to maintain its own structures. As a Marxist, Gintis could not accept that human beings' thoughts, attitudes, and behaviours were linked to secular institutions like schools. Nevertheless, Gintis was one of the few intellectuals that, rather than taking a stand for or against schools, tried to understand the method of analysis offered by Illich in his book.

However, not all engagements with Illich's ideas were critically negative. In the issue of 1974, The School Review (University of Chicago) published an article by Dididier J. Piveteau [32] entitled "Illich: Enemy of Schools or School Systems?” In this publication, Piveteau supported Illich's work and pointed out that Illich's voice was necessary because it did not allow people to neglect important ideas, and overall because, from a political logic perspective, we get a little when asking for a lot.

In France, meanwhile, two of the most prestigious reviews addressed the debate about Illich's book: Les Temps Modernes and Esprit. Les Temps Modernes, directed by Jean-Paul Sartre, published in the issue of July/August 1972 a new article by Gintis [33] entitled "Critique de L'Illichisme”. In the text the Harvard professor stated the same arguments against the methodology offered by Illich. On the other hand, in March 1972 Esprit released a monograph entitled "Illich en debat". In this issue a group of French intellectuals responded to the controversial theses against schools published in Deschooling Society. Amongst those who took part on this debate were Pierre Kende, Henri Peguignot, Paul Fraisee, Yves Goussalt, JeanWilliam Lapierre, J-P Chevènement, Pierre Causat and Michel Panoff.

Yet in the 1970's several articles arose in the area of education with the aim of analysing, synthesizing, or criticizing Illich's ideas about educational institutions. In Germany, Hartmut Von Henting [34] published his book Cuernavaca Order: Alternativen zur Schule? (1971); in France was published a book by Hubert Hannoun [35] entitled Ivan Illich ou l'école sans société (1973); in Great Britain Ian Lister [36] finished his book Deschooling: a Reader (1974); and finally, in Australia, Michael Macklin [37] launched his analysis of Illich's book entitled When Schools Are Gone. A Projection of the Thought of Ivan Illich (1976).

The division was clear in all approaches to Illich's thought: those who were against schools and those who defended educational institutions. Von Henting and Lister, who had taken part in the seminar Alternatives in Education (organized by Illich at the CIDOC in Cuernavaca between 1971 and 1972), argued that it was necessary to break up with schools and finish with their historical monopoly on education. In the meanwhile, Hannoun and Macklin labelled Illich's book as extremist and radical, and ended up defending the social performance of schools. As a result, these studies offered a minor variation on the controversy already raised in American reviews.

Finally, in Prospects, UNESCO's journal of Comparative Education, a couple of texts were published about the debate which began with Illich's ideas. This international institution ended up getting interested in the entire thematic seminar organized in Cuernavaca. Going even further, in Learning to be Edgar Faure [38] supported that these new critical works offered a new radical perspective, with the aim to de-institutionalize education and learning. As a result of the interest aroused, Prospects (which was probably the most important publication of UNESCO) published two more articles written by Ricardo Nassif and Arthur Petrovsky, both criticizing Illich's analysis.

The article published by Nassif [39] was one of the first texts written by a Latin American professor in response to Deschooling Society. The paper was entitled "The Theory of de-schooling between paradox and utopian”. In this work the Universidad Nacional de la Plata professor recognized that the approach to Illich's thought was difficult; so his book had several mistakes, tricks and absurd arguments. However, all these incoherences -from Nassif's point of view-, had a close relation with the 
doctrine of deschooling because it was by itself absurd and most likely to be a trap.

In 1976 Prospect published the article "What lies behind deschooling” by the Russian intellectual Petrovsky [40], who was at that time member of the USSR Academy of Educational Sciences and the UNESCO International Commission of Educational Development. This text was one of the most aggressive and negative responses to Illich. Petrovsky underestimated Deschooling Society, considering it a book written by a radical author whose main point was not only unoriginal but also typically ignoramus. According to Petrovsky, Illich had not paid attention to the achievements of the soviet educational system worldwide. In fact, Petrovsky maintained that only a person who was unaware of the development underwent by the Russian public school system in the 1970's, could defend these arguments against schools.

\section{Analysis of finding}

Only a few academic essays about the ideas developed by Illich in Deschooling Society have been submitted in the last forty years. The first research to be carried out with the goal of studying Illich's thought appeared at American universities in the 1970's. Only two new Master's theses were defended on this topic in the last twenty years. However, in 1999 three new works on Illich appeared in the United States and Canada.

Ten years after Deschooling Society's publication, most approaches to this book coincide with the first responses that aroused in journals and books all over the world. Three of those theses submitted between 1972 and 1974 showed this continuity very clearly. That is the case of $A$ philosophical analysis of Ivan Illich's Construct, "Deschooling society" and related terms, defended at Michigan State University by Charles Raymond Schindler [41] in 1972; also the project submitted by John Lawrence Elias [42] at Temple University in 1974 called A comparison and critical evaluation of the social and educational thought of Paulo Freire and Ivan Illich; and the research entitled Deschooling and retooling: An examination of The Philosophy of Ivan Illich with particular emphasis on his analysis of the structures of society written by Lucille C. Brush [43] at Michigan State University in 1974.

Nevertheless, a thesis carried out at Ohio University broke this trend in the analysis of Illich's book. In a work entitled Hermetic Alchemy as the Pattern for Schooling Seen By Ivan Illich in the works of Amos Comenius defended in 1973, William Ideson [44] focused his attention on one of the research lines opened in Deschooling Society. On this research, the author had the support of John Ohlinger, an expert on Illich's works and his intellectual experience. Ideson developed an interesting approach to the influence of alchemy in Amos Comenius, one of the most important figures of modern pedagogy. The goal of this project was to focus on the influence of alchemy in shaping the modern concept of education. Of particular interest on this research is that Ideson understood how Illich's thought had changed throughout his career, as seen in different texts written before and after Deschooling Society.

In 1980, a new thesis was defended at Boston University. The author was Terry Price Harte [45] and the title chosen was A critic North American Protestant theological education from the perspectives of Ivan Illich and Paulo Freire. This work can be considered as one of the first attempts to establish a dialogue between Illich and Freire. However, neither the starting point nor the way in which he presented the philosophical background of these two intellectuals had a solid foundation. Indeed, the main point of this work is the fact that proved the difficulties that the academic field of education faced in 1980's interpreting Illich's works.

It was not until the early 1990's that two new theses, both from Master's degree graduates, were defended in the United States and Canada. George Cyr of the Department of Religion and Philosophy at McGill University in Montreal [46] submitted in December 1990 an essay entitled An analysis and evaluation of Ivan Illich's social and educational philosophy in the light of his early development and the major critiques of his theories. In addition to this, in 1999 David Alan Gabbard [47], student at the University of Cincinnati, finished his thesis The second death of Ivan Illich: A theoretic-active analysis of discursive practice of exclusion.

Both theses explored superficially Illich's thought. In the case of Cyr's work, the most interesting element was the analysis that set Illich's work in the context of other authors' works, finding connections with critical studies against educational institutions. Meanwhile, Gabbard presented an attempt to resituate the philosophical thought of Illich using Michel Foucault's work as the main point of reference.

The most interesting essays carried out in the area of education on Illich's critical thinking were three theses defended in the late 1990's. These essays were the last essays to be written on this topic in an academic context, the three of them were curiously defended in 1999. In his $\mathrm{PhD}$ thesis entitled Learning without Education: Ivan Illich and the Sanctuary of The Human Presence defended at the University of Alberta, Daniel Bogert-O’Brian [48] developed an interesting philosophical study on Illich’s books. In fact, Bogert-O’Brian begins by, not only referring to Illich's ideas developed during the 1960's and the 1970's, but also by taking into account the books published by Illich after his time 
in Mexico in the 1980's. This approach allowed him to analyse continuities, ruptures, and corrections indicated by Illich since then.

Dana L. Stuchu [49], meanwhile, defended her thesis Schooling as ritual and as technology. Explorations in the social thought of Ivan Illich at Pennsylvania State University Graduate College. In her work, Stuchu presented an exploration of the ritual of schools as a technological tool for social control, using Illich's thought as a reference. In the last chapter she notably offered an analysis of schools and education as assumptions in modern discourse.

Finally, Patricia L. Inman [50] submitted her thesis An Intellectual biography of Ivan Illich to the Department of Leadership and Educational Policy Studies at Illinois University in 1999. Her work, as a matter of fact, can be considered the first work that studied Illich's thought from a historical perspective. It was also the first one to have the collaboration of Illich himself and some of his colleagues as well (Lee Hoinacki and Barbara Duden). Although it is a brief work with roughly 100 pages, Inman introduced in her thesis a review on the course of Illich's work and thought, focusing on his most important texts published up to 1999. The basis of her essay was an excellent bibliography and a detailed study of David Cayley's edition which included his interviews with Illich. Nevertheless, barely 14 pages of her thesis were devoted to the time spent by Illich in Cuernavaca at the time he published Deschooling Society.

\section{Conclusion}

In the first decade of the twentieth first century, the debate on Illich's ideas in relation to educational institutions found new approaches and analysis perspectives. Despite the fact that essays published by Illich in the 1980's and 1990's were omitted systematically from the most important academic journals of education, several interesting engagements have recently come out regarding Illich's work in different parts of the world.

One of the most important things to highlight since Deschooling Society was published in Cuernavaca is perhaps that Illich's work found support in a key group of intellectuals in Mexico the last four decades. Indeed, those who were Illich's close friends in Mexico -José María Sbert, Javier Sicilia, and Gustavo Esteva -, can be considered the most important Latin American intellectuals. They have written some of the most outstanding analyses on Illich's thought in the area of educational institutions. Throughout the 1990's, the Mexican journal Ixtus [51] was an important meeting point for this generation of intellectuals. On the issue $28^{\text {th }}$ of the publication, edited in 2000 and entitled Iván
Illich la arqueología de las certidumbres, are included texts by the authors aforementioned.

A posthumous book of Sbert [52], Epimeteo, Iván Illich y el sendero de la sabiduría published in 2009, is one of the most innovative approaches to the philosophy that underlies Illich's thinking. In this volume, colleagues of Sbert -as in the case of Jorge Márquez Muñoz-, gathered a number of significant texts which Sbert had published during the previous decade in relation to Illich's books. This essay is considered an essential work for those who want to study, or even approach, the ideas proposed by Illich.

Along the same line of Illich's thought interpretation are notable recent articles by the poet, essayist and novelist Javier Sicilia. Furthermore, Sicilia's work had a great importance in the last editions of Illich's books, published by the Mexican publishers Fondo de Cultura Económica in 2006 [53] and 2008 [54]. The prologue for the second volume was written by Sicilia. This essay is essential to understand one important key: Illich's apophatic theological perspective. From this perspective the author analyse Illich's entire work in depth.

Taking a different approach, Gustavo Esteva has linked Illich's thought with the struggle that peasant movements, urban collectives, and indigenous organizations have begun in Mexico and Latin America in recent years. From Esteva's perspective, Illich's thesis can help by reconsidering the political thought of social movements like the Zapatistas EZLN (Ejército Zapatista de Liberación Nacional), which appeared in 1994 in South-eastern Mexico. According to Esteva, the organization of this movement was based on community traditions connected to the land, an interesting alternative to the capitalist system. They could easily use Illich's thesis on conviviality as theoretical grounds for their actions.

Esteva also analyses the critique that Illich offered on educational institutions in the 1970's. The book entitled Escaping Education: Living as learning within Grassroots Cultures, published in 1998 and written together with Madhu Suri Prakash [55], can be considered the most important work discussing Illich's thought in the last two decades context. Prakash and Esteva begin by rejecting modern notions of pedagogy and education, and then, propose an analysis of the ways in which people learn by participating in grassroots movements while struggling against modernity oppression.

In the United States, meanwhile, new authors are taking into account Illich's works from different perspectives in education. A good example is the research developed in the area of ecopedagogy. After the beginning of the economic crisis in 2008, this school of thought on education started to study some of the most important articles published by Illich in the 1970's. Authors like Richard Kahn [56] 
published an interesting book that addressed works like Deschooling Society in the new global context. Indeed, his book entitled Critical Pedagogy, Ecoliteracy \& Planetary Crisis. The Ecopedagogy Movement is an attempt to bridge the thought developed forty years ago by Paulo Freire and Illich.

In a more narrow connection to these new studies on Illich's work, the first issue of The International Journal of Illich's Studies has recently presented. It is significant to mention some scholars associated with the project, such as Clay Pierce and Greg Bourassa from the University of Utah, Madhu Suri Prakash from Penn State University, and Richard Kahn from Antioch University Los Angeles. A potential problem of this new approach to Illich's texts, however, is that most of the authors have often not paid enough attention to the changes that Illich's thought experienced between the 1970's and the 1990's.

In fact, two books recently published can hardly be considered studies in which new perspectives of analysis are opened. One is entitled The Challenges of Ivan Illich, written by Lee Hoinacki and Carl Mitcham [57]; the other book is A Secular Age by Charles Taylor. Thus, a group of intellectuals all over the world, being most of them Illich's friends, gathered several texts under the title The Challenges of Ivan Illich which reviewed personal anecdotes and biographical data in order to expand the scope of interpretation of Illich's work. Even though all these texts have been published in the book aforementioned, it is not possible to find a single text analysing exclusively Deschooling Society.

\section{Conclusion and Future Work}

To conclude, it is important to mention the recent work of the philosopher Charles Taylor on Illich's thought. Taylor [58] wrote the foreword of the book The Rivers North of the Future (2005) which is considered the intellectual testament of Illich. In his foreword Taylor pointed out that Illich's ideas appear to him very revealing and enlightening. Indeed, he considered that the new analytical perspectives offered by Illich in his whole intellectual work on modern institutions led to a break in the prevailing trend among many other thinkers who, recognizing the Christian background of Western culture, had been trying to study modern society. While many intellectuals had been discussing whether modernity is the realization of Christian ideology or its antithesis, Illich changed the terms of the debate to introduce a new perspective: the possibility of studying the modern age as a perversion of Christianity.

For that reason Taylor holds that Illich's work can provide new insight into ongoing studies of modernity. In fact, in his two latest books, Modern Social Imaginaries [59] and A Secular Age [60], in his attempt to think about the epistemological break between Christianity and the ancient world, Taylor takes into account Illich's interpretation of the Good Samaritan parable and his approach to the concept of incarnation and its reverse in the institutionalization of human needs. Without doubt, this new way of interpreting Illich's book could appeal in the future to new research on one of the most important books on the history of education in the twentieth century.

\section{References}

[1] Illich, I. Deschooling Society, Harper \& Row, New York, 1971.

[2] The International Journal of Illich Studies, http://ivan-illich.org/journal/index.php/IJIS

(Accessed 8 Mar. 2011)

[3] Plessix Gray, F. D. Divine Disobedience. Profiles in Catholic Radicalism. New York: Alfred a Knopf, 1970, p. 241.

[4] Cayley, D. Ivan Illich in Conversation. Toronto: Anansi, 1992, p. 88.

[5] Hartch, T. "Ivan Illich and the American Catholic Missionary Initiative in Latin America" in International Bulletin of Missionary Research, 2009 Vol. 33. no 4 pp. 185-189.

[6] CIDOC, CIDOC Catálogo de publicaciones 1973. «CIDOC Cuaderno» $\mathrm{n}^{\circ}$ 1018. Cuernavaca: Centro Intercultural Documentación, 1973.

[7] Igelmo Zaldívar, J.; Quiroga Uceda, P. "Ivan Illich and the Conflict with Vatican (1966-1969)” in The International Journal of Illich Studies Vol. $2 \mathrm{n}^{\circ} 1$ pp. 3-12.

[8] Illich, I. The Church, Change y Development. New York: Herder and Herder, 1970.

[9] CIDOC (1969) México "entredicho" del Vaticano al CIDOC, 1966-1969. «CIDOC Dossier» $\mathrm{n}^{\circ}$ 37. Cuernavaca: Centro Intercultural de Documentación.

[10] Illich, I. Celebration of Awareness. New York: Doubleday, 1970.

[11] Illich, I. Energy and Equity, New York: Calder and Boyards, 1973.

[12] Illich, I. Medical Nemesis, New York: Calder and Boyards, 1975. 
[13] Illich, I. The Dawn of Epimethean Man and other Essays. «CIDOC Cuaderno» 54. Cuernavaca: Centro Intercultural de Documentación, 1970.

[14] Illich, I. "Why We Must Abolish Schooling” in CIDOC Alternatives in Education, July 1970-June 1971, v.1. «CIDOC Cuaderno» $\mathrm{n}^{\circ}$ 75. Cuernavaca: Centro Intercultural de Documentación, 1972. pp. 222/1-222/15.

[15] Illich, I. "Beecher Lectures" in Illich, I. Ensayos sobre la trascendencia. «CIDOC Sondeos» $\mathrm{n}^{\circ} 77$. Cuernavaca: Centro Intercultural de Documentación, 1971, pp. 1/13-13/13.

[16] Illich, I. The dawn of epimethean man and other essays. «CIDOC Cuaderno» 54. Cuernavaca: Centro Intercultural de Documentación, 1970, p. 0/4.

[17] Illich, I. "The Dawn of Epimethean man” in CIDOC Alternatives in Education, July 1970-June 1971, v. 1. "CIDOC Cuaderno» $\mathrm{n}^{0}$ 75. Cuernavaca: Centro Intercultural de Documentación, 1972, pp. 227/1-227/6.

[18] Illich, I. Shadow Work United States: SRC Press, 1980.

[19] Illich, I. Gender United States: Pantheon Books, 1983.

[20] Illich, I. In the Mirror of the Past. Lectures and addresses (1978-1990). New York: M. Boyrad. 1989.

[21] Illich, I. In the Vineyard of the Text: a commentary to Hugh's Didascalion. Chicago: University of Chicago Press, 1993.

[22] Ohlinger, J. and McCarthy, C. Lifelong Learning or Lifelong Schooling? A Tentative View of the Ideas of Ivan Illich with a Quotational Bibliography, United States: Syracuse University Press, 1971.

[23] Greer, C. “All schooled up” in Garter, A., Greer, C. and Riessman, F. (Eds.) After Deschooling, What? New York: Harper \& Row.

[24] Postman, N. "My Ivan Illich problem”, Social Policy, vol. 2, n 5, 1972, pp. 32-36.

[25] Gross, R. “After Deschooling, Free Learning”, Social Policy, vol. 2, n. 5, 1972 pp. 37-39.

[26] Farifiel, R. P. "Need for a Risk Quotiente", Social Policy, vol. 2, n. 5, 1972, pp. 39-42.

[27] Summer, M. R. “Taking Illich seriously”, Social Policy, vol. 2, n. 6, 1972, pp. 41-46.
[28] Jerome, J. “After Illich, What?”, Social Policy, vol. 2, n. 6, 1972 pp. 46-48.

[29] Green, M. “And It Still Is News”, Social Policy, vol. 2 n. 6, 1972. pp. 49-51.

[30] Pearl, A. "The Case for Schooling America”, Social Policy, vol. 2, n. 6, 1972, pp. 51-52.

[31] Gintis, H. “Toward a Political Economy of Education: A Radical Critique of Ivan Illich's Deschooling Society", Harvard Education Review, vol. 42, n.1, 1972 pp. 70-92.

[32] Piveteau, D. J. "Illich: Enemy of Schools of School Siystems?”, The School Review, vol. 82, n 3, 1974, pp. 393-411.

[33] Gintis, H. “Critique de L'Illichisme”, Les Temps Modernes, vol. 29, n. 312-313, 1972, pp. 525-557.

[34] Von Henting, H. Cuernavaca order. Alternativen zur schule?, Munich: Klett/Kösel, 1971.

[35] Hannoun, H. Iván Illich o la escuela sin sociedad. Madrid: Ediciones Península, 1976.

[36] Lister, I. Deschooling: a reader, Londres: Cambridge University Press, 1974.

[37] Macklin, M. When Schools are Gone. A Projection of the Thought of Ivan Illich, Australia: University of Queensland Press, 1976.

[38] Faure, E. Learning to be, Paris: Unesco, 1973.

[39] Nassif, R. "The Theory of de-schooling between paradox and utopian”, Prospects, vol. 5, n. 3, 1975, pp. 329-341.

[40] Petrovsky, A. V. "What lies behind deschooling”, Prospects, vol. 6, n. 1, 1976, pp. 6064.

[41] Schindler, C. R. A philosophical analysis of Ivan Illich's Construct, "Deschooling society", and related terms, $\mathrm{PhD}$ Thesis in Michigan State University (non published) pp. 96, 1972.

[42] Elias, J. L. A comparison and critical evaluation of the social and educational thought of Paulo Freire and Ivan Illich, with a particular emphasis upon the religious inspiration of their thought, $\mathrm{PhD}$ Thesis in Temple University (non published), pp. 215, 1974.

[43] Brush, L. C. Deschooling and retooling: An examination of the philosophy of Ivan Illich with particular emphasis on his analysis of the structures 
of society, PhD Thesis in Michigan State University (non published), pp. 112, 1974.

[44] Ideson, W. J. Hermetic Alchemy as the Pattern For Schooling Seen By Ivan Illich in the works of Amos Comenius, $\mathrm{PhD}$ Thesis in Ohio State University (non published), pp. 168, 1973.

[45] Harter, T. P. A critic North American Protestant Theological Education from the Perspectives of Ivan Illich and Paulo Freire, $\mathrm{PhD}$ Thesis in Boston University Graduate School (non published), pp. 371, 1980.

[46] Cyr, G. An analysis and evaluation of Ivan Illich's social and educational philosophy in the light of his early development and the major critiques of his theories, PhD Thesis in McGill UniversityMontreal (non published), pp. 132, 1990.

[47] Gabbard, D. A. The second death of Ivan Illich: A theoretico-active analysis of dicursive practice of exclusion, Master Thesis in University of Cincinnati (non published), 1991.

[48] Bobergt-O’Brien, D. H. Learning without Education: Ivan Illich and the Sanctuary of the Human Presence, PhD Thesis in University of Alberta (non published), pp. 270, 1999.

[49] Stuchul, D. L. Schooling as ritual and as technology. Explorations in the social thought of Ivan Illich, PhD thesis in Graduate School College of Education de la Pensilvania State University, (non published) pp. 197, 1999.

[50] Inman, P. L. An Intellectual biography of Ivan Illich, PhD Thesis in Department of Leadership an Educational Policy de la Northern Illinois University (non published), pp. 117, 1999.

[51] Ixtus (Eds.) “Iván Illich. La arqueología de las certidumbres”, vol. 7, n. 29, 2000.

[52] Sbert, J. M. Epimeteo, Iván Illich y el sendero de la sabiduría. México: Ediciones Sin Nombre, 2009.

[53] Illich, I. Iván Illich Obras Reunidas Vol. I. México: Fondo de Cultura Económica, 2006.

[54] Illich, I. Iván Illich Obras Reunidas Vol. II. México: Fondo de Cultura Económica, 2008.

[55] Esteva, G. and Suru Prakash, M. Grassroots Post-Modernism, Nueva York: Zed Books, 1998.
[56] Kahn, R. Critical Pedagogy, ecoliteracy \& Planetary Crisis, Nueva York: Peter Lang Publishing, 2010.

[57] Hoinacki, L. and Mitcham, C. (coor.) The Callenges of Ivan Illich, Nueva York: State University of New York Press, 2002.

[58] Taylor, C. "Foreword", Illich, I. The Rivers North of the Future. The Testament of Ivan Illich as Told to David Cayley, Canada: Anansi, 2005.

[59] Taylor, C. Modern Social Imaginaries. United States: Duke University Press, 2004.

[60] Taylor, C. A Secular Age, United States: Harvard University Press, 2007. 